\title{
Understanding the differences in cheese-making properties between reverse osmosis and ultrafiltration concentrates
}

\author{
A. Lauzin, ${ }^{1}$ Y. Pouliot, ${ }^{1 *}$ (-) and M. Britten ${ }^{2}$ (อ) \\ ${ }^{1}$ STELA Dairy Research Center, Institute of Nutrition and Functional Foods (INAF), Department of Food Science, Université Laval, Québec, \\ Canada, G1V 0A6 \\ ${ }^{2}$ Saint-Hyacinthe Food Research Center (SHFRC), Agriculture and Agri-Food Canada, J2S 8E3
}

\section{ABSTRACT}

Concentrating milk by reverse osmosis ( $\mathrm{RO}$ ) has the potential to increase cheese yield but is known to impair cheese-making properties. The main compositional differences between ultrafiltration (UF) and RO concentrates are the high lactose and mineral contents of the latter. The objective of this work was to determine the distinct effects of high lactose and high minerals on the cheese-making properties of RO concentrate, by supplementing UF concentrate with lactose. The soluble colloidal equilibria of concentrates were studied as well as several other properties: rennet gelation behavior, cheese mass balance, composition, and microstructure. Rennet coagulation time was longer and gel firming rate was lower for $\mathrm{RO}$ concentrate than for $\mathrm{UF}$ concentrate. Lactose was mainly responsible for these differences. Lactose in RO concentrate was also responsible for the $7 \%$ increase of moisture-adjusted cheese yield, relative to UF concentrate. Compared with cheese made from UF concentrate, cheese made from RO concentrate showed higher moisture content, which could not be attributed to lactose but to the high mineral concentration. This study showed the potential of using RO instead of UF concentrate to maximize cheese yield. The approach is, however, limited to applications where post-acidification can be controlled, and will require appropriate strategies to reduce the negative effects of high mineral content in RO concentrate.

Key words: reverse osmosis, lactose, cheese making, mineral equilibrium, ultrafiltration

\section{INTRODUCTION}

The concentration of cheese milk by filtration is a common practice in the dairy sector. Milk concentra-

Received February 25, 2019.

Accepted September 8, 2019.

*Corresponding author: Yves.Pouliot@fsaa.ulaval.ca tion increases the production capacity of cheese plants and increases cheese yield (Mistry, 2003). Ultrafiltration is the main process used for milk concentration, and the increase of cheese yield is attributed to higher concentration of whey proteins in the aqueous phase of cheese. The use of reverse osmosis (RO) could be of interest, because it would increase not only the concentration of whey proteins but also the concentrations of lactose and soluble minerals in the aqueous phase of the cheese.

The effects of milk ultrafiltration on cheese yield and quality have been broadly studied. Conflicting results are reported regarding the effects of UF concentration on coagulation time. Depending on different parameters, such as $\mathrm{pH}$ or protein concentration, it has been shown that the rennet coagulation time of UF concentrate was nonaffected, negatively affected, or positively affected, compared with skim milk (SM; Dalgleish, 1980; Guinee et al., 1997; Waungana et al., 1998; Mistry, 2003; Karlsson et al., 2007a; Sandra et al., 2011). However, the scientific community agrees on the effect of milk ultrafiltration on rennet gel firming rate and final firmness: they are both increased with the use of concentrate (Waungana et al., 1998; Mistry and Maubois, 2004; Thomann et al., 2008; Sandra et al., 2011). Cheese properties are also modified by milk ultrafiltration (Lelievre and Lawrence, 1988; Mistry, 2013). Depending on the concentration factor, the main compositional differences between traditional cheese and UF cheese are the moisture and mineral contents (Soodam and Guinee, 2018). Cheeses made from UF milk usually have lower moisture content due to faster syneresis compared with traditional cheeses (Mistry, 2003), and higher mineral content due to the retention of micellar calcium phosphate during concentration. The latter is responsible for the high buffering capacity of UF milk, which affects the rate of acidification by starter bacteria and the mineral concentration in the cheese.

The use of RO concentrate, evaporated milk, or skim milk powder for cheese making has been reported in 
the literature (Barbano and Bynum, 1984, 1985; Mayes, 1985; Kelly and Fox, 2016). These studies mainly describe practical approaches for use in cheese making. Increasing total milk solid concentration before cheese making was associated with cheese textural defects (Agbevavi et al., 1983), but little information is available on the effects of specific RO concentrate constituents. In a previous study, we showed that RO concentrate impaired rennet gelation properties, increasing coagulation time and lowering gel firming rate, compared with UF concentrate (Lauzin et al., 2018). The main compositional differences between RO concentrate and UF concentrate are the lactose and mineral contents, but their specific effects on cheese-making properties have not been determined. Increasing ionic strength in milk has been shown to impair the rennet coagulation properties (Zoon et al., 1989; Awad, 2007; Karlsson et al., 2007b), but the effects of high lactose content have received little attention.

In the present study, UF concentrate was supplemented with lactose (UFL) to assess its specific effects on cheese-making properties. The milk minerals content was the main compositional difference between UFL concentrate and RO concentrate, and comparing these 2 treatments provided insight on the contribution of milk minerals to the cheese-making properties of $\mathrm{RO}$ concentrate.

\section{MATERIALS AND METHODS}

\section{Production of Skim Milk and Concentrates}

Bulk pasteurized skim milk was purchased from Natrel (Québec, Canada) and stored at $4^{\circ} \mathrm{C}$ until use. Milk concentration was performed using a filtration pilot system (model 1812 Lab Unit, Filtration Engineering Company, Champlin, MN) equipped with a $0.32 \mathrm{~m}^{2}$ spiral-wound UF or RO membrane. The temperature was kept constant at $50^{\circ} \mathrm{C}$ during the process. The UF membrane used was made of polyethersulfone and had a molecular weight cutoff of $10 \mathrm{kDa}$ (Synder Filtration, Vacaville, CA). The RO membrane used was made of polyamide and was characterized by a $99 \%$ average $\mathrm{NaCl}$ rejection (General Electric, Trevose, PA). Skim milk was concentrated until it reached a total protein concentration of $7.2 \%$ (as verified by infrared analysis; Milkoscan FT120, Foss Electric, Hillerød, Denmark) and was kept at $4^{\circ} \mathrm{C}$ until use. Sodium azide (SigmaAldrich, St. Louis, MO) was added to milk concentrates $(0.02 \%, \mathrm{wt} / \mathrm{wt})$ to prevent microbial growth.

To study the effects of lactose supplementation on the properties of UF concentrate, lactose (lctose monohydrate, Thermo Fisher Scientific, Pittsburgh, PA) was added to UF concentrate to obtain a lactose-to-protein ratio similar to that of $\mathrm{RO}$ concentrate (about 1.7), as validated by infrared analysis (Milkoscan FT120, Foss Electric). After supplementation, the UFL concentrate was agitated at low speed for $3.5 \mathrm{~h}$ at $4^{\circ} \mathrm{C}$. Samples were then warmed in a water bath at $32^{\circ} \mathrm{C}$ for $1 \mathrm{~h}$ before $\mathrm{pH}$ adjustment.

The $\mathrm{pH}$ of SM and UF, UFL, and $\mathrm{RO}$ concentrates was adjusted to $6.45 \pm 0.02$ at $32^{\circ} \mathrm{C}$ with either $1 M$ $\mathrm{NaOH}$ or $10 \%$ lactic acid (Thermo Fisher Scientific). To account for the dilution factor from $\mathrm{pH}$ adjustment, the protein content of concentrates was then adjusted to $7.0 \%$ with water. After $\mathrm{pH}$ and concentration adjustments, samples were stirred at low speed at $4^{\circ} \mathrm{C}$ overnight. Samples were then warmed to $32^{\circ} \mathrm{C}$ for $1 \mathrm{~h}$ before readjusting the $\mathrm{pH}$ to $6.45 \pm 0.01$.

\section{Composition of Skim Milk and Concentrates}

After $2 \mathrm{~h}$ at $32^{\circ} \mathrm{C}$, the sedimentable and nonsedimentable phases of SM and concentrates were separated by ultracentrifugation at $100,000 \times g$ for 90 min (Optima XPN-90 ultracentrifuge, Beckman Coulter, Brea, CA). The supernatants were carefully collected, filtered through a $0.45-\mu \mathrm{m}$ polyethersulfone filter and stored at $4^{\circ} \mathrm{C}$ until analysis. The concentration of diffusible minerals was determined on dialysates. Water of HPLC grade $(10 \mathrm{~mL})$ was loaded into dialysis tubing (6 to $8 \mathrm{kDa}$, Thermo Fisher Scientific) and immersed in 500 $\mathrm{mL}$ of SM or concentrates for $48 \mathrm{~h}$ at $4^{\circ} \mathrm{C}$ under gentle agitation to reach equilibrium. The contents of the dialysis tubing were collected and stored at $4^{\circ} \mathrm{C}$ until mineral analysis.

Skim milk concentrates and their supernatants were analyzed for total nitrogen (NT), non-protein nitrogen $(\mathrm{NPN})$, and non-casein nitrogen $(\mathrm{NCN})$ fractions by the official micro-Kjeldahl method of analysis. A nitrogen-to-protein conversion factor of 6.38 was used. The mineral content (wt/wt; calcium, sodium, phosphorus, and magnesium) of SM, concentrates, and dialysates was determined by inductively coupled plasma (ICP) analyses on dry ashes (at $550^{\circ} \mathrm{C}$ overnight), as previously described by (Lauzin et al., 2018). Lactose contents of SM and concentrates were analyzed via HPLC using a Waters chromatograph (Waters Corp., Milford, MA) equipped with a Hitachi (Foster City, CA) differential refractometer detector L-7490, a 600E controller, a column oven, and a cooled 717Plus autosampler. An ICSep ICE-ION-300 column (Transgenomic, Omaha, NE) was used with $8.5 \mathrm{mM}$ of $\mathrm{H}_{2} \mathrm{SO}_{4}\left(180 \mu \mathrm{L}\right.$ of $\left.\mathrm{H}_{2} \mathrm{SO}_{4} / \mathrm{L}\right)$ as the mobile phase at a flow rate of $0.4 \mathrm{~mL} / \mathrm{min}$. The column temperature was kept at $40^{\circ} \mathrm{C}$. Samples were prepared according to the reference method (ISO 22662, IDF 
198) with the use of Biggs-Szijarto solution. The ionic strength was calculated as previously described (Lauzin et al., 2018), using diffusible mineral concentrations.

\section{Cheese-Making Properties}

Before each test, SM and concentrates were heated to $55^{\circ} \mathrm{C}$ for $5 \mathrm{~min}$ and then cooled to $32^{\circ} \mathrm{C}$. The $\mathrm{pH}$ was adjusted to 6.45 , for the determination of rennet coagulation kinetics, and to 6.20 for model cheese making. These $\mathrm{pH}$ values were chosen to recreate conditions used for many cheeses, such as cheddar and mozzarella.

Rennet Coagulation Kinetics. A 50-g sample of SM or concentrates was supplemented with $0.02 \%$ (vol/wt) of $\mathrm{CaCl}_{2}$ (Fromagex, Rimouski, Canada) and held at $32^{\circ} \mathrm{C}$ for $10 \mathrm{~min}$. Previously diluted rennet (Fromagex; 1:10) was added to the sample to reach a final concentration of $0.01 \%$ (vol/wt). The rennet coagulation kinetics were studied by dynamic rheology as described by Perreault et al. (2016), at $32^{\circ} \mathrm{C}$. Storage modulus was recorded after renneting, and 3 parameters were extracted from the coagulation profile: the lag time $\left(\mathbf{T}_{\text {lag }}\right)$, corresponding to time to increase the elastic modulus $\left(\mathbf{G}^{\prime}\right)$ by $1 \mathrm{~Pa}$; the maximum firming rate $\left(\mathbf{V}_{\max }\right)$, corresponding to the slope at the inflexion point; and the curd firmness, estimated by the $G^{\prime}$ value measured 30 min after $\mathrm{T}_{\mathrm{lag}}\left(\mathbf{G}^{\prime}{ }_{\text {Tlag }+\mathbf{3 0}}\right)$.

Model Cheese. Fresh raw cream (Fromagerie Corneville-Agropur, Saint-Hyacinthe, Canada), previously adjusted to $38 \%$ fat, was added to SM or concentrates, to reach a true protein-to-fat ratio of 1.20. Samples $(150 \mathrm{~g})$ of standardized SM or concentrates were adjusted to $\mathrm{pH} 6.20$, supplemented with $0.02 \%$ (vol/wt) of $\mathrm{CaCl}_{2}$ (Fromagex), and kept at $32^{\circ} \mathrm{C}$ for 10 min. Rennet (Fromagex; diluted 1:10) was added to reach a final concentration of $0.01 \%$ ( $\mathrm{vol} / \mathrm{wt}$ ). Model cheeses were made according to the experimental procedure described by Morin et al., (2008). Curds were cut at a firmness of $\mathrm{G}^{\prime}=40 \mathrm{~Pa}$. Cutting time for $\mathrm{SM}$ and concentrates was determined from coagulation profiles.

Milk and whey were analyzed for total solids, protein, and fat via infrared analysis (MilkoScan FT-120; Foss North America). The moisture and ash content of cheeses were respectively determined after vacuum drying at $100^{\circ} \mathrm{C}$ for $5 \mathrm{~h}$ and burning in a muffle furnace at $550^{\circ} \mathrm{C}$ overnight. Cheese yield was recorded and moisture-adjusted yield was calculated at $50 \%$ moisture. Cheese protein and fat content were determined through mass balance calculations. Retention coefficients for protein and fat were calculated using the following equation:
Retention coefficient $=1-\left(\frac{\% \text { fat or protein in whey }}{\% \text { fat or protein in milk }}\right)$.

Microstructure. The model cheeses were stored at $4^{\circ} \mathrm{C}$ for $11 \mathrm{~d}$ after production before analysis of their microstructure. A 2-cm-thick slice was removed from the top of the cheese, and samples $(7 \times 2 \times 2 \mathrm{~mm})$ were taken from the middle of the remaining piece of cheese. For each sample 5 pieces were taken. The pieces were put in a vial containing $3 \mathrm{~mL}$ of a $2 \%$ glutaraldehyde solution in $0.1 M$ cacodylate buffer at $\mathrm{pH} 7.3$ and held at $4^{\circ} \mathrm{C}$ overnight. The next day, the fixation solution was removed and replaced with cacodylate buffer at $\mathrm{pH}$ 7.3. The samples were rinsed 3 times for $10 \mathrm{~min}$ in the $0.1 M$ cacodylate buffer ( $\mathrm{pH} 7.3$ ) before the postfixation step of a 90-min incubation in a solution containing $1 \%$ (wt/vol) osmium tetroxide in $0.1 M$ cacodylate buffer at $\mathrm{pH}$ 7.3. The rinsing step with buffer was repeated, and the samples were then dehydrated by successive steps in ethanol solution at 30,50, 70, 95, and $100 \%$ $(2 \times 10$ min for each concentration). The samples were then incubated for $40 \mathrm{~min}$ in $100 \%$ ethanol, followed by $2 \times 20 \mathrm{~min}$ in hexamethyldisilazane, before being left to dry overnight. The dried samples were fractured and mounted on an observation frame with the fractured surfaces uppermost. They were coated with gold-palladium using a sputter coater (Nanotech Semprep II, Manchester, UK) and observed via scanning electron microscope (LSM-6360LV, JEOL Ltd., Tokyo, Japan).

\section{Statistical Analyses}

All experiments were repeated 3 times. Mean values and standard deviations are reported in the tables. Significant differences were evaluated by ANOVA with Tukey tests $(\alpha=0.05)$.

\section{RESULTS AND DISCUSSION}

\section{Composition of Milk and Concentrates}

The volume of skim milk was reduced by a factor of approximately 2.1 using UF or RO processes. The overall composition of SM and concentrates is shown in Table 1. True protein and casein contents increased according to the concentration factor, but both were slightly lower $(<0.015 \%)$ in $\mathrm{RO}$ concentrate than in UF concentrate. Concentrations being expressed on a weight basis, the difference was attributed to the higher density of RO concentrate. As expected, lactose concentration was 2.1 times higher in $\mathrm{RO}$ concentrate, 
Table 1. Overall composition (mean $\pm \mathrm{SD}$ ) of skim milk and concentrates ${ }^{1}$

\begin{tabular}{|c|c|c|c|c|}
\hline Item & $\mathrm{SM}$ & UF & UFL & RO \\
\hline
\end{tabular}

${ }^{\mathrm{a}-\mathrm{d}}$ Values with different superscript letters within a row are significantly different $(P<0.05)$.

${ }^{1} \mathrm{SM}=$ skim milk; UF $=$ ultrafiltration concentrate; UFL $=$ ultrafiltration concentrate supplemented with lactose; RO $=$ reverse osmosis concentrate.

compared with SM. Lactose was added to UF concentrate to match the concentration in RO concentrate. Both lactose and total solids concentrations were similar in RO and UFL concentrates. Compared with SM, the ash content increased by a factor of 2.1 and 1.4, respectively, in RO and UF concentrates. All minerals are concentrated by reverse osmosis, whereas only colloidal minerals are concentrated by ultrafiltration. As expected, the concentration of sodium was not significantly affected by ultrafiltration, but the concentration of calcium, which is partly bound to casein micelles, significantly increased. The UF process did not modify the serum phase, and UF concentrate had similar ionic strength to SM.

The soluble and micellar phases of SM and concentrates were separated and the composition of the soluble phase analyzed (Table 2). Both UF and RO concentrates had similar soluble casein concentrations, which were higher than that of the original SM $(P<$ 0.05). However, compared with the total casein content, SM had $6 \%$ soluble casein, as opposed to approximately $5 \%$ for RO and UF concentrates. Hence, the concentration process did not significantly affect the protein equilibrium between the soluble and micellar phase, as previously observed by Ferrer et al. (2011) and Lauzin et al. (2018). Milk concentration via UF or RO modified the mineral equilibrium, resulting in a lower $(P<0.05)$ proportion of soluble multivalent ions than for SM. On average, the proportions of calcium, magnesium, and phosphorus in the soluble phase of concentrates were respectively 45,22 , and $38 \%$ lower than in SM. The micellar calcium concentration (milligrams per gram of casein) was higher in UF concentrate than in SM $(P<$ $0.05)$. The elevated temperature during filtration $\left(50^{\circ} \mathrm{C}\right)$ certainly promoted a shift of calcium from the serum phase to the micellar phase (Gaucheron, 2005). The concentration of micellar calcium was further increased in RO concentrate. The aqueous phase of milk is saturated with calcium phosphate, and when concentrated by reverse osmosis, precipitation is expected (Lauzin et al., 2019). Supplementation of UF concentrate with lactose (UFL) did not affect the soluble casein content or the mineral equilibrium, and the ratio of soluble to total milk minerals was similar to those of UF and RO concentrates.

\section{Rennet Coagulation Properties}

The coagulation profiles of SM and concentrates are presented in Figure 1, and the coagulation parameters are reported in Table 3 . The formation of rennet gel was faster in UF concentrate, with a $\mathrm{T}_{\mathrm{lag}}$ of $4.7 \mathrm{~min}$, compared with $8.6 \mathrm{~min}$ for $\mathrm{SM}(P<0.05)$. The influence of UF concentration of milk on rennet coagulation time has

Table 2. Composition (mean $\pm \mathrm{SD}$ ) of the soluble phase of skim milk and concentrates ${ }^{1}$

\begin{tabular}{|c|c|c|c|c|}
\hline Item & SM & $\mathrm{UF}$ & UFL & $\mathrm{RO}$ \\
\hline $\operatorname{Ash}(\%, w t / w t)$ & $0.46 \pm 0.01^{\mathrm{b}}$ & $0.45 \pm 0.02^{\mathrm{b}}$ & $0.40 \pm 0.02^{\mathrm{a}}$ & $0.89 \pm 0.05^{\mathrm{c}}$ \\
\hline $\mathrm{Ca}(\%$ of total $\mathrm{Ca})$ & $37.7 \pm 2.5^{\mathrm{b}}$ & $20.8 \pm 0.4^{\mathrm{a}}$ & $21.0 \pm 1.1^{\mathrm{a}}$ & $22.4 \pm 2.8^{\mathrm{a}}$ \\
\hline $\mathrm{Na}(\%$ of total $\mathrm{Na})$ & $93.3 \pm 6.1^{\mathrm{a}}$ & $82.8 \pm 15.4^{\mathrm{a}}$ & $75.6 \pm 9.2^{\mathrm{a}}$ & $78.8 \pm 6.5^{\mathrm{a}}$ \\
\hline $\mathrm{P}(\%$ of total $\mathrm{P})$ & $48.8 \pm 1.1^{\mathrm{c}}$ & $28.9 \pm 1.4^{\mathrm{ab}}$ & $26.2 \pm 0.8^{\mathrm{a}}$ & $32.0 \pm 4.2^{\mathrm{b}}$ \\
\hline Micellar calcium (mg of $\mathrm{Ca} / \mathrm{g}$ of casein) & $25.6 \pm 1.0^{\mathrm{a}}$ & $29.8 \pm 0.1^{\mathrm{b}}$ & $27.5 \pm 1.6^{\mathrm{ab}}$ & $36.2 \pm 1.3^{\mathrm{c}}$ \\
\hline
\end{tabular}

\footnotetext{
${ }^{a-c}$ Values with different superscript letters within a row are significantly different $(P<0.05)$.

${ }^{1} \mathrm{SM}=$ skim milk; UF $=$ ultrafiltration concentrate; UFL $=$ ultrafiltration concentrate supplemented with lactose; RO $=$ reverse osmosis con-
} centrate. 


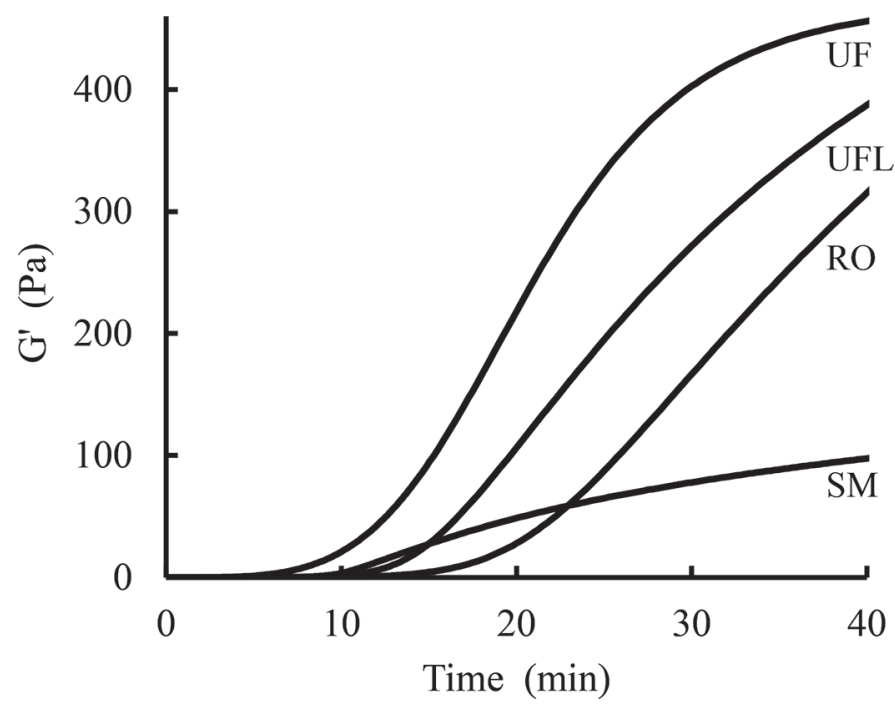

Figure 1. Elastic moduli $\left(\mathrm{G}^{\prime}\right)$ during renneting of skim milk (SM), ultrafiltration concentrate (UF), ultrafiltration concentrate supplemented with lactose (UFL), and reverse osmosis concentrate (RO).

been widely studied, and some authors have found that coagulation time was reduced (Guinee and Mulholland, 1994; Upreti et al., 2011; Soodam and Guinee, 2018), whereas others found no effect (Guinee et al., 1997; Waungana et al., 1998; Sandra et al., 2011). However, concentrating milk by $\mathrm{RO}$ increased $\mathrm{T}_{\text {lag }}(12.07 \mathrm{~min})$ compared with SM and UF concentrate $(P<0.05)$. This is in agreement with our previous study (Lauzin et al., 2018), where increased $\mathrm{T}_{\text {lag }}$ was attributed to high ionic strength and viscosity of RO concentrate. The maximal curd firming rate $\left(\mathrm{V}_{\max }\right)$ was also affected by milk concentration. Concentrate obtained via UF is known to have a higher $\mathrm{V}_{\max }$ than SM due to a crowding effect, resulting in higher collision frequency and an increased number of bonds between casein micelles (Sandra et al., 2011). We found that RO concentrate showed higher $\mathrm{V}_{\max }$ than $\mathrm{SM}(P<0.05)$ but lower $\mathrm{V}_{\max }$ than UF concentrate $(P<0.05)$. The casein content in $\mathrm{UF}$ and RO concentrates were similar, but the higher viscosity of RO could be responsible for slower micelle diffusion, resulting in a lower $\mathrm{V}_{\max }$ (Karlsson et al., 2007a). As previously shown (Table 2), the micellar calcium concentration in RO concentrate was significantly higher than in SM or in UF concentrate, which could also contribute to reduced curd firming rate. According to Malacarne et al. (2014), excessive content of micellar calcium could reduce the number of phosphate groups available for curd formation in the secondary phase of rennet coagulation. The lower curd firming rate for $\mathrm{RO}$ concentrate could represent an advantage over UF concentrate, because it increases the cutting window. The cutting window corresponds to the period during which the curd firmness is appropriate for cutting and was defined as the time between storage modulus values of 35 and $70 \mathrm{~Pa}$ (Panthi et al., 2019). As shown in Figure 1, the cutting window was $25 \%$ longer for RO concentrate than for UF concentrate. The gel firmness 30 min after coagulation $\left(\mathrm{G}^{\prime}{ }_{\text {Tlag }+30}\right)$ was higher for the concentrates than for SM $(P<0.05)$, due to the increased number of bonds between casein micelles and the higher casein volume fraction (Sandra et al., 2011). However, curd from RO concentrate showed lower $\mathrm{G}^{\prime}{ }_{\mathrm{Tlag}+30}(341 \mathrm{~Pa})$ than did UF concentrate (431 Pa).

The addition of lactose increased $\mathrm{T}_{\text {lag }}$ of UF concentrate from 4.7 to $9.9 \mathrm{~min}$ and reduced the $\mathrm{V}_{\max }$ from 26 to $19 \mathrm{~Pa} / \mathrm{min}(P<0.05)$. The lactose concentration in UFL was twice that in UF concentrate (Table 1), and according to Schorsch et al. (2002) and Famelart (1994), increasing the concentration of sugar retards both the enzymic and the aggregation steps during rennet-induced coagulation of casein micelles. It has been suggested that sugar reduces solvent quality and promotes the collapse of $\kappa$-casein molecules onto the casein micelle surface, reducing both the accessibility to chymosin and the rate of paracasein aggregation (Schorsch et al., 2002). These authors also observed lower curd firmness with increasing lactose concentration. Interestingly, the coagulation profile (Figure 1) and coagulation parameters (Table 3) of UFL concentrate fell between those of UF and RO concentrates. Lactose was, then, only partly responsible for the difference in coagulation kinetics between UF and RO concentrates. As we see in Table 3, the contribution of lactose to the differences for $\mathrm{T}_{\mathrm{lag}}, \mathrm{V}_{\max }$, and $\mathrm{G}_{\text {Tlag }+30}$ between UF and

Table 3. Rennet coagulation parameters ${ }^{1}\left(\right.$ mean \pm SD) of skim milk and concentrates ${ }^{2}$

\begin{tabular}{lcccc}
\hline Item & SM & UF & UFL & RO \\
\hline $\mathrm{T}_{\text {lag }}(\min )$ & $8.59 \pm 0.98^{\mathrm{b}}$ & $4.74 \pm 0.81^{\mathrm{a}}$ & $9.93 \pm 0.92^{\mathrm{bc}}$ & $12.07 \pm 0.21^{\mathrm{c}}$ \\
$\mathrm{V}_{\max }(\mathrm{Pa} / \min )$ & $5.4 \pm 0.8^{\mathrm{a}}$ & $26.4 \pm 0.5^{\mathrm{d}}$ & $19.0 \pm 1.4^{\mathrm{c}}$ & $16.4 \pm 0.8^{\mathrm{b}}$ \\
$\mathrm{G}^{\prime}$ Tlag+30 $(\mathrm{Pa})$ & $95 \pm 3^{\mathrm{a}}$ & $431 \pm 33^{\mathrm{c}}$ & $381 \pm 34^{\mathrm{b}}$ & $341 \pm 19^{\mathrm{b}}$ \\
\hline
\end{tabular}

\footnotetext{
${ }^{\mathrm{a}-\mathrm{d}}$ Values with different superscript letters within a row are significantly different $(P<0.05)$.

${ }^{1} \mathrm{~T}_{\text {lag }}=$ coagulation time; $\mathrm{V}_{\max }=$ maximum firming rate; $\mathrm{G}_{\text {Tlag }+30}=$ elastic modulus $\left(\mathrm{G}^{\prime}\right) 30$ min after the start of coagulation.

${ }^{2} \mathrm{SM}=$ skim milk; UF = ultrafiltration concentrate; UFL = ultrafiltration concentrate supplemented with lactose; RO $=$ reverse osmosis concentrate.
} 
RO concentrates was estimated at 71,74 , and $56 \%$, respectively. This suggests that the high mineral content in RO concentrate also affects the rennet-induced coagulation kinetics of casein micelles, but to a lower extent than lactose.

\section{Model Cheeses}

Small cheeses were produced from SM and concentrates at a laboratory scale. Cheese yield, protein and fat retention coefficients, and cheese composition are reported in Table 4 . The moisture content of cheese produced from skim milk was $46.1 \%$ and cheese yield, adjusted at $50 \%$ moisture, was $11.2 \%$. Milk concentration by UF increased cheese yield by a factor of 2.11 , which roughly corresponds to the UF concentration factor. In comparison, milk concentration by RO increased cheese yield by a factor of 2.26 , corresponding to a $7 \%$ relative increase relative to UF concentrate $(P<0.05)$. Similar protein and fat retention coefficients were observed in cheeses made from UF and RO concentrates, and the higher yield for RO cheese was attributed to the high concentration of solids in the aqueous phase of cheese. As shown in Table 4, RO cheese contained twice the amount of other solids compared with UF cheese. Adding lactose to UF concentrate increased cheese yield to a value similar to that of $\mathrm{RO}$ concentrate, confirming the significant contribution of lactose to cheese yield. Milk concentration by UF or RO had no significant effect on fat retention $(P>0.05)$ but slightly increased protein retention $(P<0.05)$. Interestingly, a higher protein retention coefficient was observed in UFL cheese than in UF or RO cheeses. Schorsch et al. (2002) suggested that sugar reduces solvent quality, which could prevent casein dissociation or caseinomacropeptide release in cheese whey. However, despite high lactose concentra- tion in $\mathrm{RO}$ cheese, its protein retention coefficient was lower than that of UFL cheese. This result suggests that high mineral concentration in $\mathrm{RO}$ concentrate could counteract the positive effect of lactose on protein retention in cheese.

Milk concentration by ultrafiltration had no significant effect on cheese moisture, but the moisture content of RO cheese was significantly higher $(50.6 \%$ vs. $47.2 \%$; $P<0.05)$. The increase of cheese moisture cannot be attributed to the higher lactose concentration in $\mathrm{RO}$ concentrate, because the moisture content of UFL cheese was similar to that of SM or UF cheeses $(P>$ 0.05). As suggested by Fagan et al. (2017), the high mineral concentration is likely responsible for higher moisture content in cheese. According to Malacarne et al. (2014), excessive mineral concentration can reduce the number of phosphate groups available for curd formation and may reduce curd contraction and syneresis during cooking. The protein-to-fat ratio was similar in $\mathrm{UF}, \mathrm{UFL}$, and RO cheeses $(P>0.05)$ and averaged 1.20 \pm 0.02 . However, it was lower in SM cheese, as expected from the lower protein retention coefficient (Table 4). The main difference among cheese compositions was the proportion of other solids, essentially composed of lactose and ash. Ash content was slightly higher in UF cheese than in SM cheese $(P<0.05)$. Because for all cheeses, whey was drained at the same $\mathrm{pH}(6.2)$, a lower proportion colloidal minerals could be solubilized when cheese was made from UF concentrate. As expected, the highest ash content was observed in RO cheese. The total milk minerals were concentrated by RO, and only a small proportion was released in whey at $\mathrm{pH}$ 6.2. The estimated lactose concentration (corresponding to the difference between other solids and ash) increased from approximately $3.0 \%$ in SM and UF cheeses to $8.9 \%$ in UFL and RO cheeses (Table 4). As previously men-

Table 4. Moisture-adjusted yield, ${ }^{1}$ retention coefficients, and composition (mean $\pm \mathrm{SD}$ ) of model cheeses made from skim milk and concentrates ${ }^{2}$

\begin{tabular}{|c|c|c|c|c|}
\hline \multicolumn{5}{|l|}{ Yield and recovery } \\
\hline Moisture-adjusted yield (\%) & $11.18 \pm 0.21^{\mathrm{a}}$ & $23.62 \pm 0.12^{\mathrm{b}}$ & $25.73 \pm 0.13^{\mathrm{c}}$ & $25.32 \pm 0.34^{\mathrm{c}}$ \\
\hline Fat retention coefficient & $0.923 \pm 0.017^{\mathrm{a}}$ & $0.935 \pm 0.012^{\mathrm{a}}$ & $0.934 \pm 0.005^{\mathrm{a}}$ & $0.922 \pm 0.008^{\mathrm{a}}$ \\
\hline \multicolumn{5}{|l|}{ Cheese composition } \\
\hline Moisture (\%,wt/wt) & $46.1 \pm 1.0^{\mathrm{a}}$ & $47.2 \pm 1.5^{\mathrm{a}}$ & $47.7 \pm 2.0^{\mathrm{a}}$ & $50.6 \pm 1.4^{\mathrm{b}}$ \\
\hline Protein (\%, dry basis) & $47.28 \pm 0.28^{\mathrm{b}}$ & $49.98 \pm 0.49^{c}$ & $47.20 \pm 0.8^{\mathrm{ab}}$ & $45.82 \pm 0.48^{\mathrm{a}}$ \\
\hline Other solids ( $\%$, dry basis) & $7.72 \pm 0.17^{\mathrm{a}}$ & $7.78 \pm 0.53^{\mathrm{a}}$ & $13.8 \pm 1.3^{\mathrm{b}}$ & $15.9 \pm 1.4^{\mathrm{b}}$ \\
\hline $\operatorname{Ash}(\%$, dry basis $)$ & $4.15 \pm 0.50^{\mathrm{a}}$ & $5.30 \pm 0.06^{\mathrm{b}}$ & $4.90 \pm 0.07^{\mathrm{ab}}$ & $7.02 \pm 0.21^{\mathrm{c}}$ \\
\hline
\end{tabular}

${ }^{\mathrm{a}-\mathrm{c}}$ Values with a different superscript letter within a row are significantly different $(P<0.05)$.

${ }^{1}$ Yield adjusted at $50 \%$ moisture.

${ }^{2} \mathrm{SM}=$ skim milk; UF = ultrafiltration concentrate; UFL = ultrafiltration concentrate supplemented with lactose; RO $=$ reverse osmosis concentrate. 

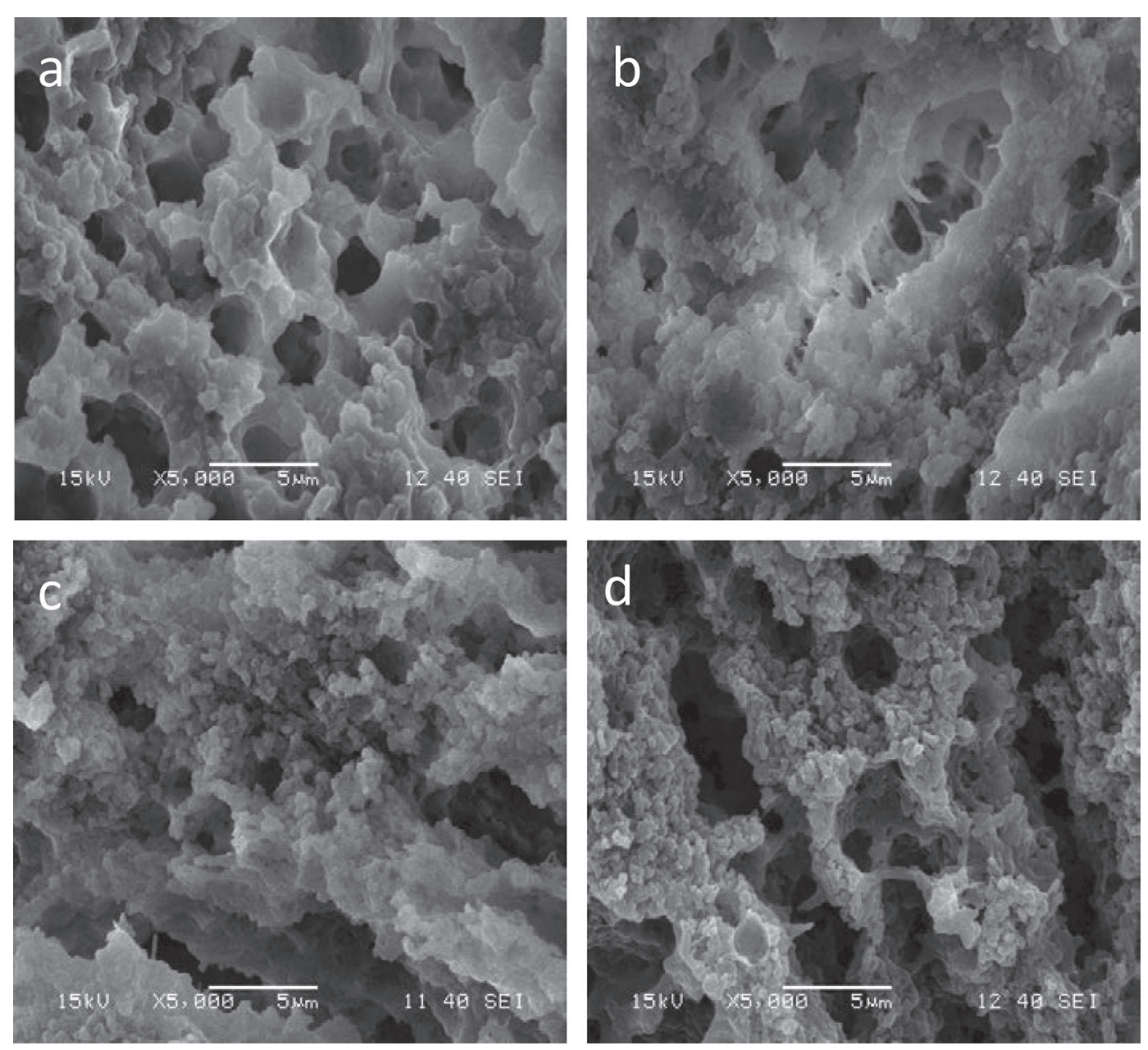

Figure 2. Scanning electron microscope images of cheese made from (a) skim milk, (b) UF concentrate, (c) UF concentrate supplemented with lactose, and (d) reverse osmosis concentrate. Bar $=5 \mu \mathrm{m}$.

tioned, lactose retention in $\mathrm{RO}$ cheese is responsible for the significant increase of cheese yield. Indeed, cheese with high lactose content is prone to post-acidification, which could result in texture and flavor defects (Moynihan et al., 2016). However, for specific applications, such as thermally treated or direct-acid cheeses, the use of RO concentrate could be a viable approach to increase cheese yield.

\section{Cheese Microstructure}

The protein networks of cheeses made from SM and concentrates were observed via scanning electron microscope, and representative micrographs are presented in Figure 2. We found that SM cheese was characterized by a continuous protein network, with homogeneously distributed void spaces corresponding to fat droplets and serum pockets removed during sample preparation (Figure 2a). The protein network was quite uniform, but individual casein micelles, forming aggregates, could be observed. In cheese made from UF concentrate (Figure 2b), larger void spaces and increased coarseness were observed. According to Green et al. (1981), increasing protein concentration via UF alters the initial curd-forming process, which determines cheese microstructure. The size of void spaces and coarseness were further increased in RO cheese (Figure 2d). The presence of aggregated casein also increased, and the individual micelles were smaller. Water in the cheese exists in different forms, and during the first weeks of storage, the bulk water decreases and the water bound to casein increases, due to casein swelling and hydration (McMahon et al., 1999). Despite higher moisture content in RO cheese (Table 4), the protein network appeared dehydrated, suggesting a higher proportion of bulk water, held within larger serum pockets. The swelling of casein micelles seemed to be very limited in cheeses made from RO concentrate. 
The addition of lactose to UF concentrate had little effect on cheese microstructure (Figure 2c), and the size of void spaces and coarseness were similar to those observed for UF cheese. The dense protein network and larger void spaces observed in RO cheese are therefore attributable to its higher mineral concentration, which promoted casein-casein interactions and prevented swelling and hydration (Joshi et al., 2004). Excessive mineralization was shown to reduce casein micelle voluminosity (De Kort et al., 2011) and is likely responsible for the lower solvation of the protein network in $\mathrm{RO}$ cheese. The microstructural characteristics of cheese made from RO concentrate may negatively affect the texture; to improve the quality of RO cheese, the cheese-making process would require adaptations to promote demineralization.

\section{CONCLUSIONS}

Making cheese from RO concentrate increased moisture-adjusted cheese yield by $7 \%$, relative to UF concentrate, due to the high lactose concentration in cheese. The kinetics of curd formation were slower in RO than in UF concentrate, and, again, lactose was mainly responsible for the difference. As a consequence, the curd cutting window was increased by $20 \%$ in RO concentrate. Cheese moisture was about $3 \%$ higher in RO cheese than in UF cheese, but the difference could not be attributed to lactose. Higher mineral concentration increased the size of serum pockets in $\mathrm{RO}$ cheese microstructure, which could explain the higher moisture content. Similar protein and fat retention coefficients were observed in cheeses made from $\mathrm{RO}$ and UF concentrates, leading to cheese compositions with the same protein-to-fat ratio. The use of RO concentrate is a viable approach to increase cheese yield. However, this approach is limited to specific applications, where post-acidification can be controlled. Our results suggest that the quality of $\mathrm{RO}$ cheeses could be improved by promoting demineralization during the cheese-making process.

\section{ACKNOWLEDGMENTS}

This work was supported by the Natural Sciences and Engineering Research Council of Canada (NSERC, Ottawa, Canada), Novalait Inc. (Québec, Canada), Fonds de recherche du Québec - Nature et technologies (FRQNT, Québec, Canada), and the Canadian Dairy Commission (CDC, Ottawa, Canada). The authors thank Amélie Bérubé from Laval University (Québec, Canada), as well as Nathalie Remillard and Hélène Giroux from Saint-Hyacinthe Food Research Center
(CRDSH, Saint-Hyacinthe, Canada) for their assistance with the experiments.

\section{REFERENCES}

Agbevavi, T., D. Rouleau, and R. Mayer. 1983. Production and quality of cheddar cheese manufactured from whole milk concentrated by reverse osmosis. J. Food Sci. 48:642-643.

Awad, S. 2007. Effect of sodium chloride and $\mathrm{pH}$ on the rennet coagulation and gel firmness. Lebensm. Wiss. Technol. 40:220-224.

Barbano, D. M., and D. G. Bynum. 1984. Whole milk reverse osmosis retentates for cheddar cheese manufacture: Cheese composition and yield. J. Dairy Sci. 67:2839-2849.

Barbano, D. M., and D. G. Bynum. 1985. Whole milk reverse osmosis retentates for cheddar cheese manufacture: Chemical changes during aging. J. Dairy Sci. 68:1-10.

Dalgleish, D. G. 1980. Effect of milk concentration on the rennet coagulation time. J. Dairy Res. 47:231-235.

De Kort, E., M. Minor, T. Snoeren, T. van Hooijdonk, and E. van der Linden. 2011. Effect of calcium chelators on physical changes in casein micelles in concentrated micellar casein solutions. Int. Dairy J. 21:907-913.

Fagan, C. C., D. J. O'Callaghan, M. J. Mateo, and P. Dejmek. 2017. The syneresis of rennet-coagulated curd. In Cheese (Chemistry, Physics and Microbiology). 4th ed. L. H. McSweeney, P. F. Fox, P. D. Cotter, and D. W. Everett, ed. Elsevier Ltd., Amsterdam, the Netherlands.

Famelart, M. H. 1994. Rennet coagulation of milk in the presence of sucrose. J. Dairy Res. 61:473-483.

Ferrer, M. A., M. Alexander, and M. Corredig. 2011. Does ultrafiltration have a lasting effect on the physico-chemical properties of the casein micelles? Dairy Sci. Technol. 91:151-170.

Gaucheron, F. 2005. The minerals of milk. Reprod. Nutr. Dev. 45:473483.

Green, M. L., A. Turvey, and D. G. Hobbs. 1981. Development of structure and texture in cheddar cheese. J. Dairy Res. 48:343-355.

Guinee, T. P., C. B. Gorry, D. J. O'Callaghan, B. T. O'Kennedy, N. O'Brien, and M. A. Fenelon. 1997. The effects of composition and some processing treatments on the rennet coagulation properties of milk. Int. J. Dairy Technol. 50:99-106.

Guinee, T. P., and O. E. Mulholland. 1994. Effect of milk protein standardization, by ultrafiltration, on the manufacture, composition and maturation of cheddar cheese. J. Dairy Res. 61:117-131.

Joshi, N. S., K. Muthukumarappan, and R. I. Dave. 2004. Effect of calcium on microstructure and meltability of part skim mozzarella cheese. J. Dairy Sci. 87:1975-1985.

Karlsson, A. O., R. Ipsen, and Y. Ardö. 2007a. Rheological properties and microstructure during rennet induced coagulation of UFconcentrated skim milk. Int. Dairy J. 17:674-682.

Karlsson, A. O., R. Ipsen, and Y. Ardö. 2007b. Influence of pH and $\mathrm{NaCl}$ on rheological properties of rennet-induced casein gels made from UF-concentrated skim milk. Int. Dairy J. 17:1053-1062.

Kelly, A. L., and P. F. Fox. 2016. Manufacture and properties of dairy powders. Pages 1-33 in Advanced Dairy Chemistry. Volume 1B, Proteins: Applied Aspects. 4th ed. P. McSweeney and J. O'Mahony, ed. Springer, New York City, NY.

Lauzin, A., A. Bérubé, M. Britten, and Y. Pouliot. 2019. Effect of pH adjustment on the composition and rennet-gelation properties of milk concentrates made from ultrafiltration and reverse osmosis. J. Dairy Sci. 102:3939-3946.

Lauzin, A., I. Dussault-Chouinard, M. Britten, and Y. Pouliot. 2018. Impact of membrane selectivity on the compositional characteristics and model cheese-making properties of liquid pre-cheese concentrates. Int. Dairy J. 83:34-42.

Lelievre, J., and R. C. Lawrence. 1988. Manufacture of cheese from milk concentrated by ultrafiltration. J. Dairy Res. 55:465-478.

Malacarne, M., P. Franceschi, P. Formaggioni, S. Sandri, P. Mariani, and A. Summer. 2014. Influence of micellar calcium and phosphorus on rennet coagulation properties of cows milk. J. Dairy Res. $81: 129-136$ 
Mayes, J. J. 1985. Dairy products manufactured from whole milk concentrated by reverse osmosis part 2-Cheddar cheese. Aust. J. Dairy Technol. 40:100-101.

McMahon, D. J., R. L. Fife, and C. J. Oberg. 1999. Water partitioning in mozzarella cheese and its relationship to cheese meltability. J. Dairy Sci. 82:1361-1369.

Mistry, V.V. 2003. Membrane processing in cheese manufacture. Pages 300-306 in Encyclopedia of Dairy Sciences. H. Roginski, J. W. Fuquay, and P. F. Fox, ed. Academic Press, Amsterdam, the Netherlands.

Mistry, V. V. 2013. Cheese. 1st ed. Blackwell Publishing Ltd., Hoboken, NJ.

Mistry, V. V., and J.-L. Maubois. 2004. Application of membrane separation technology to cheese production. Cheese (Chemistry, Physics and Microbiology), Vol. 1. 3rd ed. P. F. Fox, P. L. H McSweeney, T. M. Cogen, and T. P. Guinee, ed. Elsevier Ltd., Amsterdam, the Netherlands.

Morin, P., Y. Pouliot, and M. Britten. 2008. Effect of buttermilk made from creams with different heat treatment histories on properties of rennet gels and model cheeses. J. Dairy Sci. 91:871-882.

Moynihan, A. C., S. Govindasamy-Lucey, M. Molitor, J. J. Jaeggi, M. E. Johnson, P. L. H. McSweeney, and J. A. Lucey. 2016. Effect of standardizing the lactose content of cheesemilk on the properties of low-moisture, part-skim Mozzarella cheese. J. Dairy Sci. 99:7791-7802.

Panthi, R. R., A. L. Kelly, J. J. Sheehan, K. Bulbul, A. H. Vollmer, and D. J. McMahon. 2019. Influence of protein concentration and coagulation temperature on rennet-induced gelation characteristics and curd microstructure. J. Dairy Sci. 102:177-189.
Perreault, V., O. Turcotte, P. Morin, Y. Pouliot, and M. Britten. 2016. Combined effect of denatured whey protein concentrate level and fat level in milk on rennet gel properties. Int. Dairy J. 55:1-9.

Sandra, S., C. Cooper, M. Alexander, and M. Corredig. 2011. Coagulation properties of ultrafiltered milk retentates measured using rheology and diffusing wave spectroscopy. Food Res. Int. 44:951-956.

Schorsch, C., M. G. Jones, and I. T. Norton. 2002. Micellar casein gelation at high sucrose content. J. Dairy Sci. 85:3155-3163.

Soodam, K., and T. P. Guinee. 2018. The case for milk protein standardisation using membrane filtration for improving cheese consistency and quality. Int. J. Dairy Technol. 71:277-291.

Thomann, S., P. Schenkel, and J. Hinrichs. 2008. Effect of homogenization, microfiltration and $\mathrm{pH}$ on curd firmness and syneresis of curd grains. Lebensm. Wiss. Technol. 41:826-835.

Upreti, P., V. V. Mistry, and M. R. Acharya. 2011. Characterization of rennet coagulation of milk concentrated by vacuum condensing and ultrafiltration. Dairy Sci. Technol. 91:383-395.

Waungana, A., H. Singh, and R. J. Bennet. 1998. Rennet coagulation properties of skim milk concentrated by ultrafltration: effects of heat treatment and pH adjustment. Food Res. Int. 31:645-651.

Zoon, P., T. Van Vilet, and P. Walstra. 1989. Rheological properties of rennet-induced skim milk gels. 4 . The effect of $\mathrm{pH}$ and $\mathrm{NaCl}$. Neth. Milk Dairy J. 43:17-34.

\section{ORCIDS}

Y. Pouliot (ㄴ) https://orcid.org/0000-0002-8873-7394

M. Britten ๑ https://orcid.org/0000-0001-8538-1081 